IZA DP No. 6414

Migrant Educational Mismatch and the Labour Market

Matloob Piracha

Florin Vadean

March 2012 


\title{
Migrant Educational Mismatch and the Labour Market
}

\author{
Matloob Piracha \\ University of Kent \\ and IZA \\ Florin Vadean \\ University of Kent
Discussion Paper No. 6414
March 2012 \\ IZA \\ P.O. Box 7240 \\ 53072 Bonn \\ Germany \\ Phone: +49-228-3894-0 \\ Fax: +49-228-3894-180 \\ E-mail: iza@iza.org
}

\begin{abstract}
Any opinions expressed here are those of the author(s) and not those of IZA. Research published in this series may include views on policy, but the institute itself takes no institutional policy positions.

The Institute for the Study of Labor (IZA) in Bonn is a local and virtual international research center and a place of communication between science, politics and business. IZA is an independent nonprofit organization supported by Deutsche Post Foundation. The center is associated with the University of Bonn and offers a stimulating research environment through its international network, workshops and conferences, data service, project support, research visits and doctoral program. IZA engages in (i) original and internationally competitive research in all fields of labor economics, (ii) development of policy concepts, and (iii) dissemination of research results and concepts to the interested public.
\end{abstract}

IZA Discussion Papers often represent preliminary work and are circulated to encourage discussion. Citation of such a paper should account for its provisional character. A revised version may be available directly from the author. 
IZA Discussion Paper No. 6414

March 2012

\section{ABSTRACT \\ Migrant Educational Mismatch and the Labour Market ${ }^{*}$}

This paper reviews the literature on educational mismatch of immigrants in the labour market of destination countries. It draws on the theoretical arguments postulated in the labour economics literature and discusses their extension in the analysis of the causes and effects of immigrants' educational mismatch in the destination country. Relevant empirical approaches have been presented which show that immigrants are in general more overeducated than natives and that the reasons for those range from imperfect transferability of human capital to discrimination to perhaps lack of innate ability. It then assesses the state of current literature and proposes an agenda for further research.

JEL Classification: J24, J61

Keywords: immigration, education-occupation mismatch

Corresponding author:

Matloob Piracha

School of Economics

Keynes College

University of Kent

Canterbury, Kent CT2 7NP

UK

E-mail: M.E.Piracha@kent.ac.uk

\footnotetext{
* This paper was prepared for International Handbook of the Economics of Migration. We would like to thank two anonymous referees and the editors of the volume, Amelie Constant and Klaus Zimmermann, for helpful suggestions and comments. We are, of course, responsible for any remaining errors.
} 


\section{INTRODUCTION}

Labour market mismatch, particularly "over-education", has a long and controversial history in the labour economics literature. Freeman's (1976) book, which argued that an oversupply of university educated individuals in the US since the start of 1970s had resulted in the fall in return to education, set the scene for further research on the topic. Even though Freeman's claims were challenged in a number of papers in the subsequent few years and the issue seemed to have been resolved with Smith and Welch (1978) declaring that "at best Freeman exaggerates the case for an oversupply of college-educated manpower and that he may in fact be dead wrong", the revival came in a paper by Duncan and Hoffman (1981). Unlike the previous literature which used aggregate data, Duncan and Hoffman used individual level data and compared those who were properly matched, i.e., had required level of education, to those who had either less or more education than their job required. They found that there is indeed some "misallocation of education resources". With this paper a subfield of Economics of Over-education was born. ${ }^{2}$

In the last two decades a number of papers have extended the labour economics literature to analyse the incidence and effects of education mismatch for immigrants. The emphasis in the migration literature has been to compare the extent of over-education between natives and immigrants. This research has typically focused on the formal education qualifications of migrants and has compared their possible labour market mismatch, and in some cases the labour market mismatch of ethnic minorities, to that of natives. There is an almost universal consensus in the literature that immigrants are often more over-educated than their native counterparts and researchers have forwarded different explanations for this disparity. ${ }^{3}$ These range from imperfect transferability of human capital across borders - due to language as well as cultural and economic

\footnotetext{
${ }^{1}$ Over-education (under-education) is defined as an employee having more (less) education than their job requires.

${ }^{2}$ For a comprehensive survey of this literature see Hartog (2000), McGuinness (2006) and Leuven and Oosterbeek (2011).

${ }^{3}$ There is a general debate in the literature about the overall impact of migrants on the host country's economic and social structure. The literature has looked at migrant's level of assimilation in terms of how similar, in economic terms in general and in labour market terms in particular, they are to natives. For more discussion on this, see the chapter on Migration, Ethnicity and Economic integration.
} 
dissimilarities between home and host countries - to innate ability of immigrants to discrimination in the labour market.

This chapter presents the analysis and findings from this literature and is structured as follows. Section 2 addresses the measurement issues of educational mismatch and discusses the relevant theoretical explanations of the phenomenon from labour as well as migration economics literature. Section 3 then presents some stylised-facts on the incidence of immigrants' over- and under-education and discusses empirical findings on its determinants and its impact on wages. Section 4 explores the state of current research and offers some suggestions for further research in this area. The last section concludes the chapter.

\section{THE ECONOMICS OF EDUCATIONAL MISMATCH}

One of the key aspects of studying educational mismatch in labour markets is the way mismatch is defined/measured. We therefore first explain the various ways it has been measured in the literature and then discuss some of the theoretical explanations for education-occupation mismatch to occur.

\section{Definition and Measurement Issues}

Educational mismatch occurs when the required level of education for a particular job diverges from the employee's attained level of education. ${ }^{4}$ The level of attained education could be higher than needed for the job, in which case the worker is over-educated, or lower than required, in which case the worker is under-educated. ${ }^{5}$ There are three different ways in which the divergence from the required level of education has been measured in the literature: the first method is based on information included in job descriptions, the second method relies on workers assessments about the schooling requirements for the job they perform, while the third is a statistical method that uses data on realized matches.

\footnotetext{
${ }^{4}$ This type of mismatch is often referred in the literature as 'vertical mismatch'. On the other hand, 'horizontal mismatch' refers to employees that have acquired education in another field than their job requires (see CEDEFOP, 2010). In this paper only the 'vertical' aspects of mismatch are discussed.

${ }^{5}$ The concept of measuring over-education is controversial. For instance, one argument against this measurement is that education is typically general and is not acquired for a particular job. This then raises one of the main challenges for not only the measurement issue but one of definition of over-education as well.
} 
The job analysis method relies on the information contained in the occupational classification documents like the Dictionary of Occupational Titles (DOT), which is based on a scale of 1 to 7 . This scale is then translated into number of years of schooling from 0 to 18 . Even though this is an "objective" way to measure a mismatch and has been used by a number of authors, ${ }^{6}$ there are certain disadvantages as well. Some of the criticisms raised are the inability of the method to capture the dynamic nature of job structure as very little new information is added to the DOT on a regular basis as well as the problems resulting in measurement errors when translating job requirements into a single schooling variable (see Hartog, 2000). However, the advantage is that the education level is linked to a particular classification of occupations and is therefore relatively less subjective than the other methods.

Worker self-assessment is the most subjective of the three measures of educational mismatch and has the advantage of drawing on the current available knowledge. Workers are asked about the required education level of their job. ${ }^{7}$ However, the relevant questions included in various survey questionnaires differ significantly from each other and as demonstrated by Green et al. (1999) may lead to different answers. The answers obtained may be biased if, for example, employees associate higher status to jobs for which more education is required. In addition, even though the information may be the most up to date when asked to a recent employee, the standards/requirement are likely to have changed overtime which will not have affected someone hired prior to, say, an increase in the education levels required for the same job (Hartog, 2000). This bias could distort the extent of over-education (see Sicherman, 1991).

Finally, realized matches method has been utilized using two rather similar approaches. One, proposed by Verdugo and Verdugo (1989) is based on the mean level of schooling obtained from those who are working in the same occupations: any workers whose educational level is at least one standard deviation above the mean are deemed over-educated whereas those with one standard deviation below the mean are considered under-educated. The other approach, proposed by Kiker et al. (1997), is a variant of Verdugo and Verdugo in

\footnotetext{
${ }^{6}$ See for example, Hartog (1980), Rumberger (1987), Kiker and Santos (1991), Piracha et al. (2011).

${ }^{7}$ This method has been used by a number of authors, e.g., Hartog and Oosterbeek (1988), Duncan and Hoffman (1981), Galasi (2008).
} 
that it uses the mode, instead of the mean, of the acquired schooling for workers in the same occupation and does not use the two standard deviations interval around the centralized measure. Workers with education level more or less than the modal value are considered over- or undereducated, respectively. The main criticism of this method is, however, that the realized match does not reflect only requirements, but is the result of labour market supply and demand. This method has been used by, among others, Chiswick and Miller (2008, 2009, 2010a, 2010b, 2010c) and, with slight variations, Quinn and Rubb (2006), and Battu and Sloane (2002, 2004).

\section{Reasons for Educational Mismatches}

There is no obvious reason for an educational mismatch to occur, especially if the labour markets are assumed to function efficiently. However, the recent data shows that a substantial number (up to 50 per cent) of employed are mismatched (see Leuven and Oosterbeek, 2011). So what are the possible reasons for this divergence from the "norm"?

Education-occupation mismatch is a dynamic process that is theorised to be affected by the individual's experience in the labour market. Imperfect information, for instance, is one reason why the resultant mismatch might occur as the lack of information from both employer and potential employee perspectives cause frictions within the search-and-match context. Workers at the beginning of their career, therefore, might settle for relatively low skilled jobs in the hope that they can engage in on-the-job search in pursuit to climb the occupational ladder (see Groot and Maassen van den Brink 2000; Gautier, 2002 and Dolado et al, 2009). This "information-adjustment" model is equally relevant for immigrants as the initial search-and-match cost is relatively higher for those looking for jobs from either outside the country or soon after immigration, as they learn the new labour market structure (see Chiswick and Miller, 2009). Hence, in the initial stages of settling down, immigrants are likely to take up employment in jobs that do not match their attained education but then search for a better match while employed. With residence length and the accumulation of information about

the host country labour market, the incidence of educational mismatch is likely to fall.

Sicherman and Galor (1990) have used the career mobility/human capital 
argument to explain the education-occupation mismatch. Their model builds on the notion that workers with a given innate ability may prefer to take a job that requires less education than what they have obtained in the understanding that the cost incurred in accepting a low pay job in the initial stages will be compensated by the much higher probability of rapid promotion in the future. This theory has not been supported by empirical analysis (see Sicherman, 1991) and hence has not been used extensively in the labour economics literature; and to our knowledge has never been used in the migration literature. However, there is some scope that a variant of the human capital argument could be developed to analyze educational mismatch for immigrants.

The above reasons for a possible educational mismatch apply well to both natives and immigrants. However, there are some further reasons specific to immigrants only. For instance, ethnic minorities (e.g., both first and later generation immigrants) might be discriminated against in the labour market. ${ }^{8}$ Consequently, they would need to obtain more education for the same job to "counter" the discrimination effect.

Following Chiswick (1978), it is generally argued that immigrants are positively self-selected and, therefore, the average educational/ability level of those who arrive from abroad is likely to be higher than that of natives. ${ }^{9}$ However, the jobs they are employed in often require lower levels of education compared to their actual qualifications. More importantly, this over-education incidence is more "severe" than that of natives, i.e., immigrants are more over-educated than natives for similar kind of jobs. Chiswick and Miller (2009) have argued that one of the main reasons for immigrant over-education is the imperfect transferability of human capital across borders. This could range from lack of language skills to not being familiar with host country labour regulations to requirement of licensing for some professions. Given that there are likely to be significant differences in labour market structure between origin and host countries (e.g., employment opportunities, hiring mechanisms, etc.), especially if migration is from a less developed country to an industrialized one, immigrants would be more likely to be over-educated shortly after arrival. Then, once working in the host country for

\footnotetext{
${ }^{8}$ See chapter on Ethnic Hiring for further discussion on this.

9 Selection is also related to immigrants' visa category on which they enter the host country. See chapter on Visa Categories for Migrant Selection.
} 
some time, they would eventually move into jobs that better correspond to their education and skills.

Chiswick and Miller also found that the immigrant mismatch in the destination country is likely to be exacerbated if the individual accumulates a greater amount of work experience in the home country. ${ }^{10}$ An implicit assumption in this argument is that there was no education mismatch in the immigrants' country of origin. In other words, it is assumed that the professional experience gained prior to immigration was in jobs requiring exactly the education level obtained from formal schooling.

Piracha et al. (2011) diverge from the existing literature and argue that it is not only the education signal that determines the incidence of mismatch, but the signal from previous work experience is equally, if sometimes not more, important as an explanation for a mismatch in the host country. In other words a mismatch experience in the country of origin might significantly determine the immigrants' education mismatch probability in the host country, especially since the education signal attenuates with work experience (see Belman and Heywood, 1997). Those who were working in a job that required less education than they acquired are likely to be assessed by the host country employer to be of a lower ability than what their education might show and, hence, hired accordingly. A simple, and therefore perhaps crude, example of this is that if an individual with an engineering degree drove a taxi in his home country before migration, then he is not likely to be hired as an engineer after migrating to another country. The mismatch in that case is less likely due to discrimination and/or imperfect transferability of human capital and more likely due to the lower on-the-job skills accumulated and/or some other unobservable factors (e.g., ability, motivation, ambition, and/or energy). If, however, the individual was properly matched in the home labour market but is over-educated in the host country, then perhaps the existing explanations of imperfect skill transferability and/or discrimination could be put forward for such an outcome.

\footnotetext{
${ }^{10}$ It is worth pointing out here that it is perhaps not easy to compare the needs of a particular occupation a person has since the characteristics of a job are not usually observed in the data.
} 


\section{WHAT DO WE KNOW?}

\section{The incidence of over- and under-education among immigrants}

Most studies indicate that the incidence of education-occupation mismatch is higher among immigrants compared to natives: the percentage of correctly matched immigrant employees is, for example, about 5.0 percentage points lower compared to native employees in Denmark and reaches up to 15.6 percentage points in the United States (exceptions are Finland and Italy, where the mismatch incidence seems to be higher for natives; see Table 1). The percentage of mismatched immigrants differs from country to country with respect to the measurement method employed, the immigrant group, gender as well as the residence length. The incidence of over-education, thus, ranges from 13.2 per cent in the case of ethnic Bangladeshi in the UK to 58.1 per cent in the case of female immigrants resident in New Zealand for less than five years. On the other hand, under-education is less frequent and ranges from 5.4 per cent in the case of ethnic Indians in the UK to 44.7 per cent in the case of immigrants in the United States.

Different measurement methods often lead to significantly different estimates of incidence rates. According to Leuven and Oosterbeek (2010), studies based on the self-assessment and job analysis methods do not lead to large differences in the estimated incidence of mismatch. However, the realized matches procedure based on the mean level of schooling has generally led to lower estimated levels of over-education. ${ }^{11}$

On the other hand, Sanroma et al. (2008) found that mismatch is more frequent when self-reported rather than when objective measures are used. He argues that this is so because employees are often biased in reporting that they perform tasks above their education level. Compared to the statistically computed match rate for employees of Spanish companies - 34.3 per cent for immigrants and 39.1 for natives - only 13.1 and 18.2 per cent respectively perceived themselves to be employed in a job that matched their education level (see Table1).

The level of education mismatch in an immigrant group is often strongly linked to the definition of over-/under-education as well. For example, the low

\footnotetext{
11 That was most likely due to the fact that the two standard deviations interval around the mean - applied in the mean measurement procedure - increases the estimated number of realized matches.
} 
over-education rate (13.2 per cent) for ethnic Bangladeshi in the UK in 1993/1994 was primarily due to the low education level of the group (about 53 per cent had no qualifications; see Battu and Sloane, 2002). Individuals with a low education level can, by definition, not work below their education level. Contrarily, migrant groups with high average education are more likely to be over-educated and less likely to be under-educated, as were for example the ethnic Indian and Chinese.

The education mismatch incidence is also dependent on immigrants' characteristics and background. Poot and Stillman (2010) show that recent female migrants in New Zealand had about 6.4 percentage point higher over-education rate and a 6.1 percentage points lower under-education rate compared to their male counterparts.

Immigrants originating from countries with a similar language to that of the host country seem to have also a significantly better matching rate. As illustrated by Green et al. (2007), immigrants in Australia coming from an English speaking background had about 10 percentage points lower over-education rates compared to Asian immigrants.

\section{Mismatch dynamics}

The dynamics of education mismatch have received little attention compared to its determinants and wage effects that we review in the next two sections. The few studies that touched the issue showed that there is important persistence in education mismatch (see Mavromaras et al., 2009). Simultaneously, however, there are significant labour market integration dynamics at work. In New Zealand, for example, the incidence of over-education decreased after five years of residence for both male (from 51.7 to 41.0 per cent) and female (from 58.1 to 42.9 per cent) immigrants, while the rates of correctly matched and undereducated immigrant employees rose accordingly (see Table 1; Poot and Stillman, 2010). Newly arrived immigrants are usually employed in jobs that are below their education level since host country employers are generally not properly able to assess foreign qualifications. However, once employed for a period of time, skilled immigrants have the possibility to prove their abilities on-the-job and to climb correspondingly the occupation ladder.

Two dynamics are of particular interest in the case of immigrants: a) education mismatch transitions between home and host country and b) education 
mismatch transitions in the host labour market. To our knowledge the only paper that captures both these dynamics is Piracha et al. (2011). Using Australian data and a job analysis method to measure education mismatch, Piracha et al. illustrate the persistence in education-occupation mismatch. The biggest share of immigrants who were over-educated in their last job in the home country $(41.1$ per cent) remained over-educated in their first job in Australia, while only 19.4 per cent of them found a job to match their qualification at five months after arrival (see first part of Table 2). However, from those who were correctly matched in their last job in the home country, almost 60 per cent found jobs at their education level immediately after arrival, while over 63 per cent of those who worked above their education level (i.e., were under-educated) before migration found jobs at or above their education level at five months after arrival in Australia. The second part of Table 2 illustrates that despite educational mismatch persistence, about 30 per cent of those initially over-educated at five months after immigration managed to find within one more year of residence a job to match their qualification.

The labour market integration dynamics have been also confirmed by Huber et al. (2010) in the case of immigrants in EU-15 countries (see Table 3). They showed that for both medium and high skilled migrants in the EU-15 the average over-education rate of those with more than 10 years of residence (13.5 and 23.1 per cent respectively) was only about half of that for medium and high skilled migrants with less than 10 years of residence (27.8 and 49.6 per cent respectively).

\section{What causes education mismatch?}

The determinants of over- and under-education are usually estimated using binary outcome or multinomial models. The specifications vary widely, making the comparison of results quite difficult. A further complication is that several studies do not take into account the eventual important selection bias into employment. Education mismatch is observed only for employed individuals and immigrant unemployment rates are sometimes considerable. Piracha et al. (2011) indicate that over 30 per cent of the immigrants are unemployed at 5 months after arrival in Australia. Moreover, some studies have separate estimations for males and females (e.g., McGoldrick and Robst ,1996), education levels (e.g., Poot and 
Stillman, 2010) or residence periods (e.g., Piracha et al., 2011), while others run pooled estimations over population groups and/or time periods (e.g., Green et al. 2007; Sanroma et al., 2008; Chiswick and Miller, 2009).

Nevertheless, more or less coherent findings are that more recent immigrants, with less work experience, less fluent in the host country language, as well as originating from countries that are economically and culturally different are more likely to be over-educated.

The country or region of origin is one of the most frequently analysed determinants for immigrants' education mismatch. The reason for that is that it may eventually hide two important aspects related to easier labour market integration in the host country: 1) the quality of schooling and/or labour market experience in the home country and 2) the cultural and language similarities between home and host country. By analysing the intensity of mismatch (i.e., more than five years of over-education vs. less then five years of over-education), Sanroma et al. (2008) found that immigrants in Spain originating from a developed country had a considerably smaller likelihood of being severely mismatched (only 3.6 per cent) compared to those originating from Eastern Europe, the Maghreb countries or Sub-Saharan Africa (over 20 per cent). The most plausible explanation for that is that local employers put a low value on qualifications from education systems in developing countries as well as on the work experience gained in those countries.

Sanroma et al. (2008) further found that cultural and language proximity between the immigrants' home country and Spain reduces the intensity of overeducation as well, with immigrants from Latin America being less over-educated compared to East European, Asian and African migrants. These results were confirmed by studies on other host countries. Using a self-assessment measurement method of over-education, Mavromaras et al. (2009) estimated that the likelihood of immigrants from non-English speaking countries to be moderately over-educated in the Australian labour market is 12.9 per cent and that of being severely over-educated is 14.2 per cent higher compared to natives. At the same time, they found no significant effect for immigrants from an English speaking background. Similarly, Green et al. (2007) and Poot and Stillman (2010) confirm that originating form an English speaking country (e.g., British Iles, North America) decreases the likelihood and/or intensity of over-education in 
Australia and New Zealand respectively. All these finding give support to the hypothesis of imperfect transferability of human capital.

There are several possible strategies to improve the transferability of home country human capital. One is to have the home country qualifications assessed. Green et al. (2007) show, however, qualification assessment policy introduced in Australia in the 1990s had contradictory effects. Having a home country qualification assessed in Australia decreases the probability of over-education by 19 per cent for migrants with an English speaking background and by 14 per cent for Asian migrants, but increased it by 8 per cent for other migrants with a nonEnglish speaking background.

Another strategy is to obtain a host country qualification. Nielsen (2007) shows that immigrants in Denmark that have Danish education have three times lower probability of being over-educated compared to those having a foreign diploma. Battu and Sloane (2002) argue that foreign employers are more likely to recognise foreign qualifications. They found that working for a non-white employer decreases over-education of non-whites in the UK by 16.6 per cent and increases under-education by 2.8 per cent. Moreover, working in an urban areathat eventually draws in highly skilled labour and generates positive spillover benefits of such labour pooling - has been found to decreases the intensity of over-education by 1.3 per cent for immigrants with no qualification and up to 28.5 per cent for immigrants with bachelor degrees (Poot and Stillman, 2010).

The hypothesis of imperfect transferability of human capital predicts also that with the accumulated host country labour market experience the immigrants' labour market situation should improve. The pace of assimilation can be, however, slow. Sanroma et al. (2008) estimated that it would need about 15 years for immigrants living in Spain to close the educational mismatch gap between them and natives. A quicker pace was found for Eastern Europeans, and immigrants from the Maghreb. However, for Asians and Sub-Saharan Africans the gap seem not to narrow at all. Immigrants from these regions being at high risk to remain permanently trapped in the Spanish labour market in jobs with lower wages, regardless of their level of education.

By estimating a multinomial model of mismatch, Chiswick and Miller (2009) found that residence/experience in the US help migrants to climb up the occupational ladder. The predicted over-education rate decreased after 30 years of 
residence from 34.3 to 25.0 per cent, while the predicted under-education rate increased from 36.5 to 46.9 per cent. Nevertheless, they found that the experience in home country had an even stronger effect: 30 years of home country labour market experience decreasing the predicted over-education rate from 36.2 to 23.2 per cent and increasing the under-education rate from 21.4 to 53.7 per cent. They explain this result by the probably favourable selection of migrants with respect to skills valued in the US labour market.

Among other countries, Australia has long experience of migrant selection on the basis of point system that assesses the potential immigrants' labour market skills. The merits of such a selection is confirmed by the findings that migrants who were not selected on the basis of skills (e.g., preferential family and concessional family visa holders) had highest likelihood of being over-educated in the Australian labour market.

A quite important but often neglected cause of immigrants' education mismatch is previous education mismatch experience in the home country. As shown by Piracha et al. (2011) the home country mismatch significantly adds to the explanation of the variation in the immigrants' mismatch in Australia. Compared to a model that has as covariates only socio-economic controls used in other studies (i.e., age, age squared, a dummy for having the qualification assessed in Australia, dummies for the former region of residence, dummies for the entry visa type, a dummy for school age children present, a dummy for having financial funds at time of entry, and regional dummies), the inclusion of covariates controlling for the mismatch in the home country almost doubles the explanatory power of the probit estimation for over-education at five months after arrival in Australia (i.e., adjusted R-square increase from 0.14 to 0.26 ) and almost quadruples the explanatory power of probit estimation for under-education at five months after arrival (i.e., adjusted R-squared increase from 0.14 to 0.51 per cent). The findings show that at time of arrival in the host country, employers use the available information about the immigrants' labour market experience in the home country to derive ability signals from it.

\section{How does mismatch affect wages?}

The main model used in the literature to estimate the returns to over- and under-education is the so-called ORU (over-, required-, under-education) model. 
It is an extended Mincerian wage equation introduced by Duncan and Hoffman (1981) and has the form:

$\ln \left(w_{i}\right)=\propto_{o} E_{i}^{o}+\propto_{r} E_{i}^{r}+\propto_{u} E_{i}^{u}+x_{i}^{\prime} \beta+\varepsilon_{i}$

where $w_{i}$ is individual's $i$ wage, $E_{i}^{o}$ are the number of years of surplus or overeducation, $E_{i}^{r}$ are the number of years of required education for the job, $E_{i}^{u}$ are the number of years of deficit or under-education, and $x_{i}^{\prime}$ are a vector of control variables, including experience and experience squared. The actual years of education for the individual $i$ are either $E_{i}^{r}, E_{i}^{r}+E_{i}^{o}$ or $E_{i}^{r}-E_{i}^{u} ; E_{i}^{o}$ and $E_{i}^{u}$ cannot be simultaneously positive (i.e., the individual cannot be both over- and under-educated at the same time).

The estimations of equation (1) face two often ignored problems: a) omitted variable bias (i.e., individuals are likely to be non-randomly assigned with respect to both completed and required education), and b) measurement error with respect to required education (as alluded to in Section 2; also see Section 4 for further discussion on this issue). The solutions are far from trivial and some scholars have tried to address them using instrumental variables and individual fixed effects models (for a more detailed discussion see Leuven and Oosterbeck, 2011).

Duncan and Hoffman's (1981) model has been replicated extensively using different data and, sometimes, different measures of required education. ${ }^{12}$ The general findings are that: a) in a job requiring a given amount of education, the earnings of over-educated employees are higher, while the earnings of undereducated employees are lower compared to employees who have the required education level; b) the returns to years of education above the level required as well as the 'penalty' for the years of education below the level required are both lower than the returns to the years of required education; and c) under-education is less severely punished than over-education is rewarded (see Hartog, 2000; Leuven and Oosterbeck, 2011).

The empirical findings focusing on immigrants summarized in Table 4 are

\footnotetext{
${ }^{12}$ A quite special case is Battu and Sloane (2002 and 2004). They have used dummies for overand under-education instead of years, making the results incomparable with those from other studies.
} 
in accordance with the general estimation results mentioned above. Moreover, immigrants' returns to required schooling seem to be quite similar to those of natives and amount between about 8 per cent in Denmark to about 15 per cent in the United States and Australia. Nevertheless, immigrants seem to get significantly less return from over-education, but also a lower penalty to undereducation. Immigrants in the United States, for example, have 4.5 per cent higher wages for each year of surplus education (compared to 5.4 per cent for natives) and a -2.2 per cent penalty for each year of education deficit (compared to -6.6 per cent for natives).

There are important variances with respect to migrants' origin. Immigrants in Spain originating form the EU-15 and North America had similar returns to education compared to natives. At the same time, immigrants from Eastern Europe and Africa had 3.4 and 5.9 percentage points respectively lower returns to required schooling and no returns to over-education (see Sanroma et al., 2008).

Fluency in the host country language certainly improves the international transferability of human capital. Originating from a country with more similar culture and language seems to increase not only the probability of a matched employment (as discussed above), but the returns to education as well. Chiswick and Miller (2010c) found that immigrants in Australia originating from an English speaking country have 2.4 percentage points higher returns to each year of overeducation. Similarly, Latin American immigrants in Spain had higher returns to both required and surplus education compared to East Europeans and Africans (see Sanroma et al., 2008).

Another aspect is the familiarity of employers with credentials held. Nielsen (2007) differentiated between immigrants in Denmark with foreign vs. host country education and found that the last ones had 2.6 percentage points higher returns per year of over-education and 0.7 percentage points higher returns to each year of required education.

Chiswick and Miller (2010a) tested whether returns to schooling vary with the quality of the foreign education obtained. They estimated a two-step model that has the ORU equation as first step. In the second step equation, the payoff coefficients from the first are used as dependent variable and the PISA (Programme for International Student Assessment) scores as well as the GDP per 
capita for the countries of origin as explanatory variables. They found that a better education acquired abroad in terms of PISA test scores (a 100 points increase) is associated with greater returns to required education (1.0 to 1.4 per cent) on the US labour market, modest returns to surplus education ( 0.3 to 0.4 per cent), and a greater penalty to years of under-education (-1.3 to -1.6 per cent). This suggests that employers assess, at least partly, objectively the skills and abilities of immigrants with different backgrounds.

\section{POSSIBLE EXTENSIONS}

Research work on the topic may be extended in two different directions of equal relevance. The first relates to the more general problems of measurement error and omitted variable bias already mentioned. While there have been first attempts to tackle the problems using individual fixed effects and instrumental variables estimations (see Dolton and Silles, 2008; Korpi and Tahlin, 2009; Tsai, 2010), the use of these econometric models is limited by the availability of suitable data. Individual fixed effects can be applied only for panel data (which is quite scarce with respect to immigrants), while the second demands good instruments for required and completed education (e.g., information on individual ability and motivation, number of siblings, economic problems and/or disruptions in the family of origin, etc.) are seldom available in immigrants' surveys. Perhaps better theoretical foundations and more appropriate data collection could disentangle some of the elements that affect the results.

The second direction is related to specific research questions in the field of international migration. While so far immigrants' educational mismatch has been analysed only with respect to its determinants and effects on wages, there is still little or nothing known on the mismatch effect on the migrants' self-employment, integration, return migration, and remittance decisions as well as the consequent effects for migrant sending countries.

In case migrants working in job below their education level decide to settle abroad, could over-education in the labour market cause immigrants to become self-employed? And/or, if foreign employers in the destination country are more likely to recognise foreign qualifications than native employees (as found by Battu and Sloane, 2002 and 2004), would that cause migrants to become more encapsulated in their own ethnic group in terms of both labour activity and 
social life, even if that is more likely to undermine their integration process in the host society?

Stark and Taylor (1991) argued that immigrants might decide to return to their home countries if they rank higher in the income distribution of their home reference group compared to that of their reference group in the host country (i.e., relative deprivation). Could education mismatch make immigrants feel "relatively deprived" and contribute to return decisions? If over-education is an important aspect of the return decision of highly educated migrants, does that not undermine the expectations of "brain drain" compensations through transfer of know how and technology (as they probably gained no professional experience in high skilled jobs)?

Another important impact of possible labour market mismatch in the destination country is likely to be on immigrants' remittance behaviour. If there is, for instance, a high incidence of over-education then, as the existing literature shows, that will result in relatively lower wages compared to correctly matched levels, which can then have a negative impact on remittance flows. ${ }^{13}$

\section{CONCLUSIONS}

This chapter has reviewed the possible causes and consequences of educational mismatch of immigrants in the labour market of their countries of destination. Within the labour economics literature, the issue of over- and undereducation is controversial and has been under discussion for a number of years. However, research on educational mismatch of immigrants is still in its infancy and there is rather limited research in this area. The extant literature has shown that immigration, at least in the initial stages, has not been successful in allocating skills of the new entrants efficiently. This result has been shown when comparing with natives for a number of high immigrant-receiving countries (e.g., Australia, the US, Canada). A number of reasons have been forwarded for this mismatch including imperfect transferability of human capital, the lack of host country language skills, the lack of innate ability, and discrimination.

\footnotetext{
${ }^{13}$ To date, however, only the study of McDonald and Valenzuela (2009) considers the effect of over-education on remittance behaviour. Using the data on Filipino migrants, they found that overeducated women tend to remit less but the mismatch has no impact on men in the same category. Men tend to work longer hours to compensate for the lower wage.
} 
This survey has therefore not only explored the theoretical and empirical literature on immigrant mismatch but also presented some possible directions for further research. We see scope for a lot of interesting work to be done on the effects of immigrants' education mismatch on self-employment and integration in the host country as well as on return migration and remittances. Moreover, the measurement error and omitted variable bias problems related to required and completed education leave the estimation of mismatch effects a challenging econometric exercise. 


\section{REFERENCES}

Battu, H. and P.J. Sloane (2002), 'To what extent are ethnic minorities in Britain over-educated?', International Journal of Manpower, 23(3), 192-208.

Battu, H. and P.J. Sloane (2004), 'Over-education and ethnic minorities in Britain', The Manchester School, 72(4), 535-559.

Belman, D and J.S. Heywood (1997), 'Sheep skin effects by cohort: Implications of job matching in a signaling model', Oxford Economic Papers, 49, 623-637.

CEDEFOP (2010), 'The skill matching challenge. Analysing skill mismatch and policy implications', Luxembourg: European Union.

Chiswick, B.R. (1978), 'The effect of Americanization on the earnings of foreignborn men', Journal of Political Economy, 86(5), 897-921.

Chiswick, B.R. and P.W. Miller (2008), 'Why is the payoff to schooling smaller for immigrants?', Labour Economics, 15(6), 1317-1340.

Chiswick, B.R. and P.W. Miller (2009), 'The international transferability of immigrants' human capital skills', Economics of Education Review, 28(2), 162169.

Chiswick, Barry R. and Paul W. Miller (2010a), 'The effects of school quality in the origin on the payoff to schooling for immigrants', in Gil Epstein and Ira Gang (eds.), Migration and Culture, Frontiers of Economics and Globalization, Vol. 8, Emerald Publishing, Bingley, 67-103.

Chiswick, Barry R. and Paul W. Miller (2010b), 'Education mismatch: Are highskilled immigrants really working at high-skilled jobs and the price they pay if they aren't?', in Barry R. Chiswick (ed.), High Skilled Immigration in a Global Labor Market, Washington D.C.: American Enterprise Institute Press, 111-154.

Chiswick, B. R. and P.W. Miller (2010c), 'The effects of educationaloccupational mismatch on immigrant earnings in Australia, with international comparisons', International Migration Review, 44(4), 869-898.

Dolado, J. J., M. Jansen, and J.F. Jimeno (2009), 'On the job-search in a matching model with heterogeneous jobs and workers', Economic Journal, 119, 200-228.

Dolton, P. J. and M.A.Silles, (2008), 'The effects of over-education on earnings in the graduate labour market', Economics of Education Review, 27(2), 125 - 139.

Duncan, G. and S. Hoffman (1981), 'The incidence and wage effects of overeducation', Economics of Education Review, 1(1), 75-86.

Freeman, Richard (1976), The Overeducated American. Academic Press.

Galasi, P. (2008), 'The effect of educational mismatch on wages for 25 countries', Budapest Working Papers on the Labour Market BWP - 2008/8. 
Gautier, P. (2002), 'Unemployment and search externalities in a model with heterogeneous jobs and workers', Economica, 69, 21-40.

Green, C., P. Kler, and G. Leeves (2007), 'Immigrant overeducation: Evidence from recent arrivals to Australia', Economics of Education Review, 26(4), 420432.

Green, F., S. McIntosh and A. Vignoles (1999), 'Overeducation and skills clarifying the concepts', CEPDP 435. Centre for Economic Performance, London School of Economics and Political Science.

Groot, W. and H. Maassen van den Brink (2000), 'Overeducation in the labor market: A meta-analysis', Economics of Education Review, 19(2), 149-158.

Hartog, J. (2000), 'Over-education and earnings: Where are we, where should we go?', Economics of Education Review, 19(2), 131-147.

Hartog (1980), 'Earnings and capability requirements', Review of Economics and Statistics, 62 (2), 230-240.

Hartog, J. and H, Oosterbeek (1988), 'Education, allocation and earnings in the Netherlands: Overschooling?', Economics of Education Review, 7(2):185-94.

Huber, P., M. Landesmann, C. Robinson and R. Stehrer (2010), 'Migration, Skills and Productivity', Research Report 365, The Vienna Institute for International Economic Studies.

Kiker, B. F., and M.C. Santos (1991), 'Human capital and earnings in Portugal', Economics of Education Review, 10 (3), 187-203.

Kiker, B., M.C. Santos and M. de Oliveira (1997), 'Overeducation and undereducation: Evidence for Portugal', Economics of Education Review, 16(2), $111-125$.

Korpi, T. and M. Tahlin (2009), 'Educational mismatch, wages, and wage growth: Overeducation in Sweden, 1974-2000', Labour Economics, 16:183-193.

Leuven, E. and H. Oostorbeek (2011), 'Overeducation and mismatch in the labor market', IZA Discussion Paper No. 5523, Bonn.

Mavromaras, K., S. McGuinness and Y.K. Fok (2009), 'Overskilling dynamics and education pathways', IZA DP No. 4321.

McDonald, J. T. and M. R. Valenzuela (2009), 'The impact of skill mismatch among migrants on remittance behaviour', Social and Economic Dimensions of an Aging Population Research Papers 242, McMaster University.

McGoldrick, K. and J. Robst (1996), 'Gender differences in overeducation: A test of the theory of differential overqualification', American Economic Review, 86(2), 280-284. 
McGuinness, S. (2006), 'Overeducation in the labour market', Journal of Economic Surveys, 20(3), 387-418.

Nielsen, C.P. (2007), 'Immigrant overeducation: Evidence from Denmark', Policy Research Working Paper Series 4234, The World Bank.

Piracha, M., M. Tani and F. Vadean (2011), 'Immigrant over- and undereducation: The role of home country labour market experience', KDPE 1105, School of Economics, University of Kent, UK.

Poot, J and S. Stillman (2010), 'The importance of heterogeneity when examining immigrant education-occupation mismatch: Evidence from New Zealand', IZA Discussion Paper No. 5211.

Quinn, M. and S. Rubb (2006), 'Mexico's labor market: The importance of education-occupation matching on wages and productivity in developing countries', Economics of Education Review, 25:147-156.

Rumberger, R.W. (1987), 'The impact of surplus schooling on productivity and earnings', Journal of Human Resources, 22(1), 24-50

Sanroma, E., R. Ramos and H. Simon (2008), 'The portability of human capital and immigration assimilation: Evidence from Spain', IZA Discussion Paper No 3649 .

Sicherman, N. (1991). "“Overeducation" in the labor market', Journal of Labour Economics, 9(2), 101-122.

Sicherman, N. and O. Galor. (1990), 'A theory of career mobility', Journal of Political Economy, 98(1):169-192.

Stark O. and J.E. Taylor (1991), 'Migration incentives, migration types: The role of relative deprivation', The Economic Journal 101 (408): 1163-78.

Smith, J. and F. Welch (1978), 'The overeducated American? A review article', UCLA Economics Working Papers 147.

Tijdens, K.G. and M. van Klaveren (2011), 'Over- and underqualification of migrant workers. Evidence from WageIndicator survey data', Working Papers 110, Amsterdam Institute for Advanced Labour Studies.

Tsai, Y. (2010), 'Returns to overeducation: A longitudinal analysis of the U.S. labor market', Economics of Education Review, 29(4), 606 - 617.

Verdugo, R. and N. Verdugo (1989), 'The impact of surplus schooling on earnings: Some additional findings', Economics of Education Review, 22(4), 690695. 
Table 1: The incidence of educational mismatch among immigrants and natives

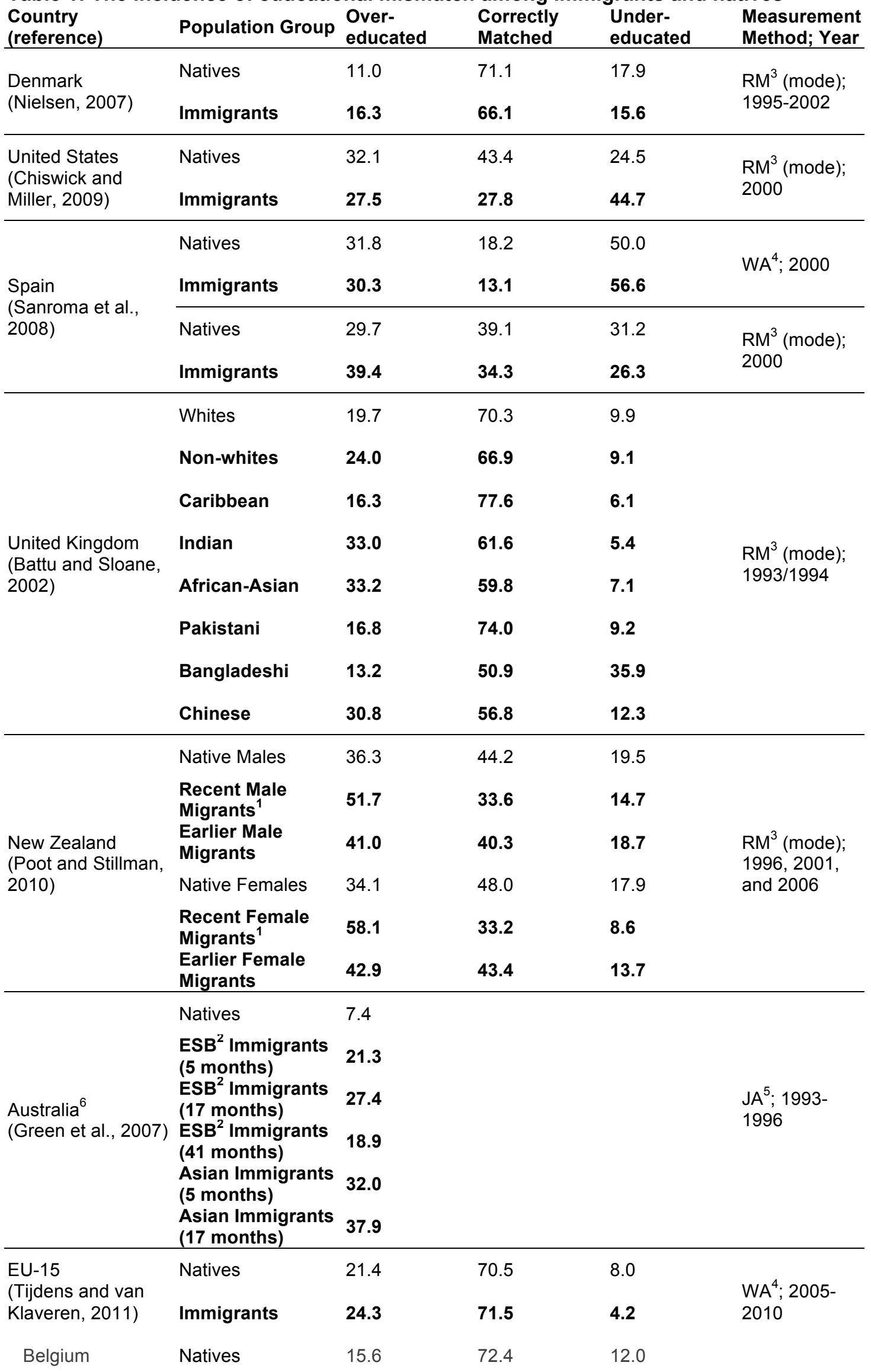




$\begin{array}{lllll} & \text { Immigrants } & \mathbf{2 3 . 6} & \mathbf{6 7 . 5} & \mathbf{8 . 9} \\ \text { Denmark } & \text { Natives } & 18.9 & 77.8 & 3.3 \\ & \text { Immigrants } & \mathbf{4 4 . 6} & \mathbf{5 4 . 3} & \mathbf{1 . 0} \\ \text { Finland } & \text { Natives } & 26.3 & 68.6 & 5.1 \\ & \text { Immigrants } & \mathbf{2 6 . 9} & \mathbf{6 9 . 7} & 3.4 \\ \text { France } & \text { Natives } & 13.2 & 80.8 & 6.0 \\ & \text { Immigrants } & \mathbf{2 2 . 3} & \mathbf{7 5 . 6} & \mathbf{2 . 1} \\ \text { Italy } & \text { Natives } & 19.5 & 68.1 & 12.3 \\ & \text { Immigrants } & \mathbf{1 7 . 1} & \mathbf{7 7 . 5} & \mathbf{5 . 4} \\ \text { Netherlands } & \text { Natives } & 18.1 & 68.9 & 13.1 \\ & \text { Immigrants } & \mathbf{2 6 . 1} & 63.6 & 10.3 \\ & \text { Natives } & 20.7 & 76.2 & 3.1 \\ \text { Sweden } & \text { Immigrants } & \mathbf{2 3 . 3} & \mathbf{7 2 . 8} & 3.9\end{array}$

Notes: 1) Recent migrants resided in New Zealand for less than five years; 2) ESB - English speaking background; 3) RM - realised matches procedure; 4) WA - worker self-assessment procedure; 5) JA - job analysis procedure; 6) Green et al. estimated the incidence for overeducated only. 
Table 2: Transition matrix of education mismatch Education mismatch in home Education mismatch in Australia - 5 months after arrival country

\begin{tabular}{llllll}
\hline & Unemployed & $\begin{array}{l}\text { Over- } \\
\text { educated }\end{array}$ & $\begin{array}{l}\text { Correctly } \\
\text { matched }\end{array}$ & $\begin{array}{l}\text { Under- } \\
\text { educated }\end{array}$ & Total \\
\cline { 2 - 6 } Over-educated & 39.1 & 41.1 & 19.4 & 0.4 & 100 \\
Correctly matched & 26.5 & 12.0 & 59.2 & 2.3 & 100 \\
Under-educated & 33.9 & 2.8 & 17.0 & 46.3 & 100 \\
\hline \hline
\end{tabular}

\section{Education} mismatch in Australia - 5 Education mismatch in Australia - 17 months after arrival months after arrival

\begin{tabular}{llllll}
\hline & Unemployed & $\begin{array}{l}\text { Over- } \\
\text { educated }\end{array}$ & $\begin{array}{l}\text { Correctly } \\
\text { matched }\end{array}$ & $\begin{array}{l}\text { Under- } \\
\text { educated }\end{array}$ & Total \\
\cline { 2 - 6 } Over-educated & 6.1 & 61.5 & 30.1 & 2.3 & 100 \\
Correctly matched & 3.0 & 6.5 & 86.1 & 4.4 & 100 \\
Under-educated & 4.5 & 1.2 & 15.7 & 78.6 & 100 \\
\hline
\end{tabular}

Source: Piracha et al. (2011); data are from the Longitudinal Survey of Immigrants to Australia (LSIA); pooled Cohort 1 and 2; male immigrants only.

Table 3: Share of over-educated Immigrants aged 15+ by skill level, country of residence, and duration of stay

\begin{tabular}{|c|c|c|c|c|}
\hline \multirow[t]{2}{*}{ Receiving country } & \multicolumn{2}{|c|}{$\begin{array}{l}\text { less than } 10 \text { years of } \\
\text { residence }\end{array}$} & \multicolumn{2}{|c|}{$\begin{array}{l}\text { more than } 10 \text { years of } \\
\text { residence }\end{array}$} \\
\hline & $\begin{array}{l}\text { Medium } \\
\text { skilled }\end{array}$ & High skilled & $\begin{array}{l}\text { Medium } \\
\text { skilled }\end{array}$ & High skilled \\
\hline EU-15 & 27.8 & 49.6 & 13.5 & 23.1 \\
\hline Austria & 22.9 & 29.5 & 18.8 & 29.1 \\
\hline Belgium & 19.3 & 31.9 & 12.2 & 25 \\
\hline Denmark & (17.4) & 36.7 & (10.4) & 16.8 \\
\hline Spain & 36.6 & 72.9 & 17.4 & 29.7 \\
\hline France & 22.9 & 41.5 & 12.9 & 21.3 \\
\hline Greece & 33.8 & 72.9 & 25.7 & 53.2 \\
\hline Italy & 27.3 & 60.9 & 15.7 & 27.5 \\
\hline Luxembourg & (11.9) & (4.6) & (5.4) & (4.4) \\
\hline Netherlands & 23.1 & 29.1 & 11.6 & 17.5 \\
\hline Portugal & 25.9 & 52.9 & 7.8 & 13 \\
\hline Sweden & 17.4 & 39 & 8.9 & 26.1 \\
\hline UK & 21.5 & 29.2 & 11.7 & 21.5 \\
\hline
\end{tabular}

Source: EU-LFS. Notes: medium skilled $=$ ISCED 3,4; high-skilled $=$ ISCED 5,6; values in brackets have a low reliability. 
Table 4: Wage effect of educational mismatch among immigrants and natives

\begin{tabular}{|c|c|c|c|c|c|}
\hline $\begin{array}{l}\text { Country } \\
\text { (reference) }\end{array}$ & Population Group & $\begin{array}{l}\text { Over- } \\
\text { education }\end{array}$ & $\begin{array}{l}\text { Required } \\
\text { Education }\end{array}$ & $\begin{array}{l}\text { Under- } \\
\text { education }\end{array}$ & $\begin{array}{l}\text { Measurement } \\
\text { Method }\end{array}$ \\
\hline \multirow{2}{*}{$\begin{array}{l}\text { United States } \\
\text { (Chiswick and } \\
\text { Miller, 2008) }\end{array}$} & Natives & $0.056^{* * *}$ & $0.153^{* \star *}$ & $-0.066^{* * *}$ & \multirow{2}{*}{$\begin{array}{l}\mathrm{RM}^{5} \text { (mode) } \\
\text { procedure }\end{array}$} \\
\hline & Immigrants & $0.045^{\star \star *}$ & $0.153^{\star \star *}$ & $-0.022^{\star \star \star}$ & \\
\hline \multirow{2}{*}{$\begin{array}{l}\text { United States } \\
\text { (Chiswick and } \\
\text { Miller, 2010b) }\end{array}$} & \multirow{2}{*}{$\begin{array}{l}\text { Natives } \\
\text { (Bachelor+) }^{1} \\
\text { Immigrants } \\
\text { (Bachelor+) }^{1}\end{array}$} & $0.020^{* * *}$ & $0.122^{\star \star \star}$ & & \multirow{2}{*}{$\begin{array}{l}\mathrm{RM}^{5} \text { (mode) } \\
\text { procedure }\end{array}$} \\
\hline & & $0.019^{* * *}$ & $0.140^{* \star *}$ & & \\
\hline \multirow{2}{*}{$\begin{array}{l}\text { United States } \\
\text { (Chiswick and } \\
\text { Miller, 2010b) }\end{array}$} & \multirow{2}{*}{$\begin{array}{l}\text { Natives } \\
(\text { Master }+)^{2} \\
\text { Immigrants } \\
{\text { (Master }+)^{2}}^{2}\end{array}$} & $0.027^{* * *}$ & $0.132^{* \star \star}$ & & \multirow{2}{*}{$\begin{array}{l}\mathrm{RM}^{5} \text { (mode) } \\
\text { procedure }\end{array}$} \\
\hline & & $-0.018^{* * *}$ & $0.091^{* * *}$ & & \\
\hline \multirow{3}{*}{$\begin{array}{l}\text { Australia } \\
\text { (Chiswick and } \\
\text { Miller, 2010c) }\end{array}$} & Natives & $0.060^{\star \star \star}$ & $0.152^{\star \star *}$ & $-0.037^{\star \star \star}$ & \multirow{3}{*}{$\begin{array}{l}\mathrm{RM}^{5} \text { (mode) } \\
\text { procedure }\end{array}$} \\
\hline & \multirow{2}{*}{$\begin{array}{l}\text { ESB }^{3} \\
\text { Immigrants } \\
\text { non-ESB } \\
\text { Immigrants }\end{array}$} & $0.056^{\star \star *}$ & $0.152^{\star \star \star}$ & $-0.027^{\star \star \star}$ & \\
\hline & & $0.032^{\star \star \star}$ & $0.152^{* \star *}$ & $-0.014^{\star * *}$ & \\
\hline \multirow{3}{*}{$\begin{array}{l}\text { Australia } \\
\text { (Chiswick and } \\
\text { Miller, 2010c) }\end{array}$} & Natives & $0.053^{\star \star *}$ & $0.112^{\star \star \star}$ & $-0.083^{* * *}$ & \multirow{3}{*}{$\mathrm{JA}^{6}$ procedure } \\
\hline & $\begin{array}{l}\text { ESB }^{3} \\
\text { Immigrants }\end{array}$ & $0.053^{\star \star \star}$ & $0.127^{\star \star \star}$ & $-0.060^{\star \star \star}$ & \\
\hline & $\begin{array}{l}\text { non-ESB } \\
\text { Immigrants }\end{array}$ & $0.035^{\star * \star}$ & $0.096^{* * *}$ & $-0.052^{\star * *}$ & \\
\hline \multirow{6}{*}{$\begin{array}{l}\text { Spain } \\
\text { (Sanroma et al., } \\
2008 \text { ) }\end{array}$} & Natives & $0.044^{* * *}$ & $0.090^{* \star \star}$ & $-0.043^{* * *}$ & \multirow{6}{*}{$\begin{array}{l}\mathrm{RM}^{5} \text { (mode) } \\
\text { procedure }\end{array}$} \\
\hline & $\begin{array}{l}\text { Immigrants } \\
\left(E U-15 \& A^{4}\right)\end{array}$ & $0.044^{* * *}$ & $0.098^{* \star *}$ & $-0.051^{* * *}$ & \\
\hline & $\begin{array}{l}\text { Immigrants } \\
\text { (Rest Europe) }\end{array}$ & -0.003 & $0.056^{* * *}$ & $-0.054^{\star \star \star}$ & \\
\hline & $\begin{array}{l}\text { Immigrants } \\
\text { (Rest America) }\end{array}$ & $0.017^{\star \star *}$ & $0.065^{\star \star \star}$ & $-0.042^{* \star *}$ & \\
\hline & $\begin{array}{l}\text { Immigrants } \\
\text { (Africa) }\end{array}$ & 0.001 & $0.031^{* \star *}$ & $-0.017^{* * *}$ & \\
\hline & $\begin{array}{l}\text { Immigrants } \\
\text { (Asia) }\end{array}$ & 0.018 & $0.100^{* * *}$ & $-0.046^{\star * *}$ & \\
\hline \multirow{3}{*}{$\begin{array}{l}\text { Denmark } \\
\text { (Nielsen, 2007) }\end{array}$} & Natives & $0.054^{* \star *}$ & $0.079^{* \star *}$ & $-0.047^{* * *}$ & \multirow{3}{*}{$\begin{array}{l}\mathrm{RM}^{5} \text { (mode) } \\
\text { procedure }\end{array}$} \\
\hline & $\begin{array}{l}\text { Immigrants } \\
\text { (Danish educ.) }\end{array}$ & $0.037^{* \star *}$ & $0.079^{\star \star \star}$ & $-0.032^{* * *}$ & \\
\hline & $\begin{array}{l}\text { Immigrants } \\
\text { (foreign educ.) }\end{array}$ & $0.011^{* * *}$ & $0.072^{\star \star \star}$ & $0.019^{*}$ & \\
\hline
\end{tabular}

Note: 1) Bachelor+ - individuals with bachelor or higher education; 2) Master+ - individuals with master or higher education; 3) ESB - English speaking background; 4) NA - North America; 5) RM - realised matches procedure; 6) JA - job analysis procedure. 